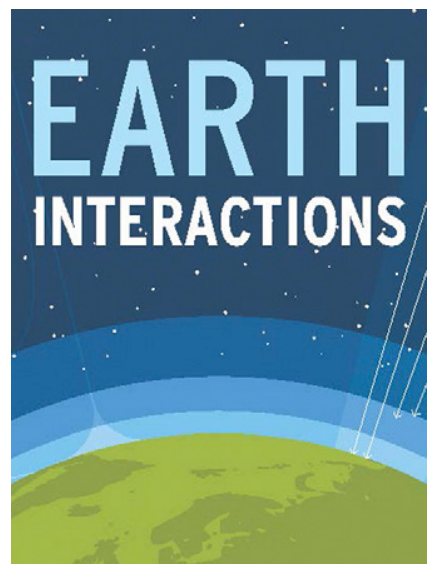

(C) 2018 American Meteorological Society. For information regarding reuse of this content and general copyright information, consult the AMS Copyright Policy (www.ametsoc.org/PUBSReuseLicenses).

\title{
Average Protein Content and Its Variability in Winter Wheat: A Forecast Model based on Weather Parameters
}

\section{Dr. Elisabeth Vollmer ${ }^{\mathrm{a}}$ and Prof. Oliver Mußhoff ${ }^{\mathrm{a}}$}

Faculty of Agricultural Sciences, Farm Management Group, Department of Agricultural Economics and Rural Development, Georg-August-University Göttingen, Göttingen, Germany

Received 9 July 2018; in final form 3 October 2018

\begin{abstract}
In this article, the effect of different weather parameters on the mean height and the variability of the protein content in winter wheat is investigated. The analysis is based on the proteins of 148800 wheat deliveries in Mecklenburg-Western Pomerania during 2004-15. From April to July, the forecast model was estimated with the following weather parameters: temperature sum, daily temperature range, precipitation, and sunshine duration. A Just and Pope function was estimated as a random intercept model. In addition to the weather parameters, a dummy variable is integrated into the forecast model to record differences in quality between $\mathrm{A}$ and $\mathrm{B}$ wheat varieties. The results show that $76.5 \%$ of the annual variability of the mean protein content can be explained
\end{abstract}

a Corresponding authors: Dr. Elisabeth Vollmer, elisabeth.vollmer@agr.uni-goettingen.de; Prof. Oliver Mußhoff, oliver.musshoff@agr.uni-goettingen.de 
Earth Interactions - Volume 22 (2018) • Paper No. 19 • Page 2

on the basis of these weather parameters. In contrast, weather variables can only explain a small part of the variance in protein content per se.

KEYWORDS: Regional models; Stochastic models; Agriculture

\section{Introduction}

Germany is regarded as a major exporter of quality wheat with high protein content. In addition to supplying domestic demand, exports are an important sales channel for German wheat. As 3.13 million hectares are used for winter wheat (corresponding to $27 \%$ of arable land), this underlines the importance of wheat cultivation for agriculture in Germany (Statistisches Bundesamt 2017).

Agriculture, as well as upstream and downstream sectors, is faced with uncertainty in a wide variety of ways. Agricultural production is influenced by environmental factors, with weather conditions having an important influence on the yield and quality of products (Moschini and Hennessy 2001). Since wheat production is found to be sensitive to weather variability (Porter and Semenov 2005), the climatic change-characterized, for example, by a higher frequency and higher magnitude of extreme weather events-is important in this context (Semenov 2009). As a result, farmers are confronted with so-called risk-based decisions. For example, if farmers use preharvest marketing techniques, they need information on their expected quality in addition to information about their expected harvest quantity due to production risk (Moschini and Hennessy 2001). In addition, these variations in quality are an important challenge for dealers, mills, and other customers in the market, since a constant quality of the goods is required (Jarvis et al. 2008). The crude protein content in particular, as an indirect indicator of baking quality, is used as an important criterion to classify the wheat quality in German agricultural trade. Thus, having information on the expected protein content before harvest would be advantageous for all market players. As the farmer cannot make a reliable statement about the future crude protein content by choice of variety and $\mathrm{N}$ fertilization alone, and since other market players possibly do not even have information on choice of variety or $\mathrm{N}$ fertilization, a forecasting model could provide valuable information (Koch 2011; Häner and Brabant 2016).

In the literature, several studies can be found that develop forecasting models for wheat quality with different approaches for different regions using weather parameters. For example, Pan et al. (2006) developed regression models for protein content based on field experiments in China using weather parameters. Johansson and Svensson (1998) also used field experiments from Sweden and tested not only the protein content, but also other baking properties for their dependence on protein content. Furthermore, Jarvis et al. (2008) investigated the influence of weather variables on several baking properties using wheat samples from Canadian farms. Dalla Marta et al. (2011) analyzed the protein content of Italian durum wheat varieties with not only classical weather parameters, but also a reference to largescale weather indices of entire continents. Lee et al. (2013) estimated yield and protein content models with weather data for the United States from the United States Department of Agriculture (USDA). All these studies provide evidence that it is possible to develop reliable models in order to predict the protein content based on the weather parameters. However, for Germany, there are only studies that focus 
Earth Interactions - Volume 22 (2018) • Paper No. 19 • Page 3

on the relation of weather parameters to yield, not to protein content. ${ }^{1}$ In other words, there has been no investigation of the specific influence of weather parameters on protein content (neither mean protein content nor variance of protein content). Numerous reasons such as different vegetation periods, soil types, and cultivation systems mean that previous studies from other regions cannot be directly transferred to Germany (Dixon et al. 1994).

In addition, the studies quoted on the influencing factors of protein content are limited to the estimation of the protein content's level itself. However, it would be interesting to find out how the variability of the protein content is also influenced by weather parameters. Especially for mills and the baking industry, fluctuating qualities can lead to processing problems (Peterson et al. 1998). While the literature contains various studies that analyze the influence that weather parameters have on protein content, there are no studies (to our knowledge) that analyze the influence weather factors have on the protein content variability. This research gap can be closed by estimating a stochastic production function developed by Just and Pope $(1978,1979)$. Just and Pope (JP) production functions are a well-established form of production functions that have already been applied in the context of wheat production and weather variables. For example, Chen et al. (2004) estimated a JP function from U.S. data. They investigated the influence of temperature and precipitation, among other variables, on the average yield and variability of five crops, including wheat. Furthermore, Carew et al. (2009) examined the mean yield and yield variance of summer wheat in the Canadian province of Manitoba. In addition to input variables such as different types of fertilizer, they also used indices for soil quality and biodiversity, as well as the weather parameters of rainfall and temperature. Cabas et al. (2010) used JP production functions for maize, soybeans, and winter wheat in Ontario, Canada. In addition to actual inputs, the authors investigated the effects of climatic variables on the mean and variance of the products. In summary, existing studies using the JP function consider yield response to various weather parameters. The JP function has not been utilized to analyze the impacts weather has on protein content response.

Against this background, the aim of this research is to develop a model for forecasting the protein content of winter wheat and the variability of the protein content, using a JP function estimated with a random intercept model. The investigation is based on weather information from 16 weather stations in Mecklenburg-Western Pomerania and protein data from 2004 to 2015. Mecklenburg-Western Pomerania is the focus since it is an important region for arable farming in Germany. In this region, wheat is grown in only $31 \%$ of the area (Statistisches Bundesamt 2017). Weather data are combined with information from a total of 148800 protein samples, which are aggregated into quantity-weighted mean values according to districts classified by postcode. To maximize the benefits of the prediction model for practice, a broadly applicable model is used without restrictions according to specific wheat varieties, soil types, and fertilizer variants. For farmers, the model could provide decision support for marketing decisions. Preliminary estimates of expected winter wheat quality are also useful for downstream industries that will receive the harvested grain for processing, storage, or resale.

\footnotetext{
${ }^{1}$ For Germany, Erekul and Köhn (2006) analyze the influence of the weather parameters on the yield of wheat and triticale. Chmielewski and Köhn (2000) investigate the question for rye.
} 
Earth Interactions - Volume 22 (2018) • Paper No. 19 • Page 4

Thus, this article extends the existing literature in three decisive aspects. First, it is the first study to analyze the effects of weather parameters on the protein content of wheat and the variability of the protein content in Germany. To the best of our knowledge, a JP function has not been applied in this context until now. Second, it is also the first article to analyze monthly weather variables in a random intercept model. Third, for the first time, a protein prediction model based on a broad selection of protein data from an entire region, and not on field tests from a limited number of sites, is determined, which takes the weather parameters of temperature, temperature sum difference, precipitation, and sunshine hours into account. These parameters were selected based on previous research. The studies to date relating to protein content and weather indicate that higher temperatures in the grain-filling phase in particular have a positive influence on protein content (Benzian and Lane 1986; Johansson and Svensson 1998; Smith and Gooding 1999; Dalla Marta et al. 2011; Lee et al. 2013).

Outcomes from previous studies show no clear results for precipitation. Depending on the study design, either a positive effect of higher precipitation (Lee et al. 2013) or a negative influence was observed (Smith and Gooding 1999; Dalla Marta et al. 2011). Some studies also found that sunshine duration had a positive influence on protein content (Johansson and Svensson 1998; Pan et al. 2006). Furthermore, the thesis shows that larger differences between day and night temperatures increase the protein content (Pan et al. 2006). In the aforementioned studies, different approaches were followed with respect to the time periods of the observed weather data. To predict the variance of the protein content, no hypotheses can be justified from the literature, since research work has not taken up this aspect so far.

The remainder of the paper is structured as follows. In section 2, the analytical approach and its adjustments for the estimation of protein content as well as the data structure are explained. Section 3 then describes the existing dataset. Section 4 presents the estimation results for the weather parameters on protein levels and the variability. Finally, in section 5, the discussion and conclusions of this work follow.

\section{Methods}

A JP function is estimated to investigate the influence of different weather variables on the mean protein content of winter wheat and the variance of the protein content. With the JP function, the mean protein content and the variance of the protein content can be estimated separately. The advantage of this separation is that a detailed specification is possible for both subfunctions. In addition, the sign of a parameter can be different in both parts of the function (Asche and Tveterås 1999). The basic JP model can be represented as follows:

$$
y_{i t}=f\left(x_{i t}, \alpha\right)+u_{i t}=f\left(x_{i t}, \alpha\right)+\varepsilon_{i t} \sqrt{h\left(x_{i t}, \beta\right)} .
$$

Here, $y_{i t}$ is protein content in region $i$ in year $t$ as a function of weather parameters recorded in $x_{i t}$. Function $f\left(x_{i t}, \alpha\right)$ is the deterministic part of the production function that relates weather parameters to the average protein content. Moreover, $u_{i t}$ depicts the heteroscedastic error term, which can be rewritten as $u_{i t}=$ $\varepsilon_{i t} \sqrt{h\left(x_{i t}, \beta\right)}$. In this formulation, $\sqrt{h\left(x_{i t}, \beta\right)}$ is the stochastic component of the function that displays the dependence between the weather parameters and the 
variance of the protein content. Term $\varepsilon_{i t}$ is the error term that is assumed to be independent and identically distributed (i.i.d.): $\varepsilon_{i t} \sim N\left(0, \sigma_{\varepsilon_{i t}}^{2}\right)$.

A weather parameter can have a different influence on the mean protein content $E\left(y_{i t}\right)=f\left(x_{i t}, \alpha\right)$ and on its variance $\operatorname{Var}\left(y_{i t}\right)=\operatorname{Var}\left(u_{i t}\right)=\varepsilon_{i t}^{2} h\left(x_{i t}, \beta\right)$. The partial derivative of the variance with respect to a weather parameter $x_{i t}$ shows the marginal influence of this weather parameter on the variability of the protein content, which can be positive, negative, or equal to zero:

$$
\frac{\partial \operatorname{Var}\left(y_{i t}\right)}{\partial x_{i t}}=\frac{\partial h\left(x_{i t}\right)}{\partial x_{i t}}<=>0 .
$$

This is an important feature since there should not be an a priori constraint on the sign of a parameter on the variance (Just and Pope 1978).

A two-step approach (Just and Pope 1979) is used to estimate Equation (1), and this is adapted to estimate the equation of a mixed model with a random intercept (Fahrmeir et al. 2013). This model was selected based on the given data structure with repeated measurements at the same weather stations over time. A random intercept model, which is considered to be a special type of mixed model, is estimated for both the mean and the variance function. ${ }^{2}$

In the first step, the deterministic part of the function, the function of mean protein content, is estimated. A quadratic function is assumed to estimate the mean protein content:

$$
y_{i t}=\gamma_{0 i}+\alpha_{0}+\sum_{k=1}^{K} \alpha_{k} x_{k i t}+0.5 \sum_{k=1}^{K} \sum_{j=1}^{J} \alpha_{k j} x_{k i t} x_{j i t}+D_{\text {Quality }}+u_{i t} .
$$

In this random intercept model, there is a station-specific intercept $\gamma_{0 i}+\alpha_{0}$. Term $\alpha_{0}$ is the fixed, region-independent base value for which local variances $\gamma_{0 i}$ exist and are calculated. This random intercept encompasses the unobserved, timeinvariant heterogeneity in the data [e.g., soil type and specific (time constant) climatic condition]. The station-specific random intercepts $\gamma_{0 i}$ are assumed to be i.i.d.: $\gamma_{0 i} \sim N\left(0, \tau_{0}^{2}\right)$. Furthermore, they are supposed to be mutually independent from the error term $u_{i t}$. The random intercepts can be interpreted as effects of unavailability, time-invariant, station-specific covariates, and they account for unobserved heterogeneity (Fahrmeir et al. 2013). To control for the variety-related protein potential in a model, the dummy variable $D_{\text {Quality }}$ is integrated into the prediction model.

The additive interaction between the mean and variance function in this quadratic specification is consistent with the postulates formulated by Just and Pope (1978). This is in contrast with the translog specification, wherein the stationspecific effect would be multiplicative (Eggert and Tveterås 2004; Tveterås and Wan 2000).

The error term $u_{i t}$ has an expected value of zero, and the residuals of the different observations are assumed to be uncorrelated (Just and Pope 1979). The variance of the protein content is a function of levels of weather parameters (Griffiths and Anderson 1982; Just and Pope 1979):

\footnotetext{
${ }^{2}$ The random intercept models are estimated using the "Ime4" package for the statistical program "R" developed by Bates et al. (2015).
} 


$$
\begin{gathered}
\text { Earth Interactions } \bullet \text { Volume } 22(2018) \cdot \text { Paper No. } 19 \text { Page } 6 \\
\qquad \operatorname{Var}\left(u_{i t}\right)=E\left(u_{i t}^{2}\right)=E\left[\varepsilon_{i t}^{2} h\left(x_{i t}, \beta\right)\right]=\sigma_{\varepsilon}^{2} h\left(x_{i t}, \beta\right) .
\end{gathered}
$$

Based on the estimates from the range $\alpha_{1}, \ldots, \alpha_{K}$, the values of the residuals $\hat{u}_{i t}$ are calculated. Subsequently, these residuals are used to estimate the stochastic component of the JP function in the second step. Because of the common assumption of $\sigma_{\varepsilon}^{2}=1$, we get the following equation based on Equation (4):

$$
\hat{u}_{i t}^{2}=h\left(z_{i t}, \beta\right) \text {. }
$$

Also for the variance function, a random intercept model is estimated. A CobbDouglas (CD) functional form is assumed: ${ }^{3}$

$$
\ln \left(\hat{u}_{i t}^{2}\right)=\delta_{0 i}+\beta_{0}+\sum_{k=1}^{K} \beta_{k} \ln \left(x_{k i t}\right)+D_{\text {Quality }}+v_{i t} .
$$

The station-specific deviations around the common fixed intercept $\beta_{0}$ are displayed by $\delta_{0 i}$. The vector $\beta$ represents the fixed common slope parameters, and $v_{i t}$ is the error term. The advantage of the $\mathrm{CD}$ function is that the coefficients can be directly interpreted as elasticities of the individual weather parameters.

\section{Data}

Weather and protein data from Mecklenburg-Western Pomerania are used to estimate the JP function for predicting the protein content of winter wheat. The research region is a coastal federal state in northeastern Germany (see Figure 1).

The climate is characterized by a transition from the maritime influence near the coastal area of the Baltic Sea to a continental type inland. The average annual temperature is $8.3^{\circ} \mathrm{C}$. The average rainfall per year is between 550 and $610 \mathrm{~mm}$, with decreasing precipitation from the coast to inland areas (Climate Data 2016). Over the last 10 years, the wheat harvest has started, on average, at the end of July. The months April-July are used for the analysis, as spring and the phases of grain filling and ripening - in which literature shows an influence of weather parameters on the protein content-fall within this period. The filling phase is an especially important factor in grain formation, since $70 \%-80 \%$ of the protein is formed at this stage of development (Stone and Savin 1999). This begins about 8-10 weeks before the harvest, which corresponds to the middle/end of May.

Sixteen weather stations of the German Weather Service in MecklenburgWestern Pomerania have provided the weather data used in the study from 2004 to 2015. The map of Mecklenburg-Western Pomerania in Figure 2 shows the location of the weather stations in the study region.

In the case of a missing daily value, these data were replaced by the values of the nearest station. This procedure is common in literature and is suggested by Qian et al. (2009), among others. For each station, the daily measured values were aggregated to monthly sums. Although the developmental stages of wheat do not exactly coincide with the calendar months, the use of monthly sums or mean values of weather variables instead of the exact biological growth periods is widespread.

\footnotetext{
${ }^{3}$ The combination of a quadratic mean function with a variance function in logarithms is a commonly used procedure in the literature. Examples are Koundouri and Nauges (2005) or Gardebroek et al. (2010).
} 


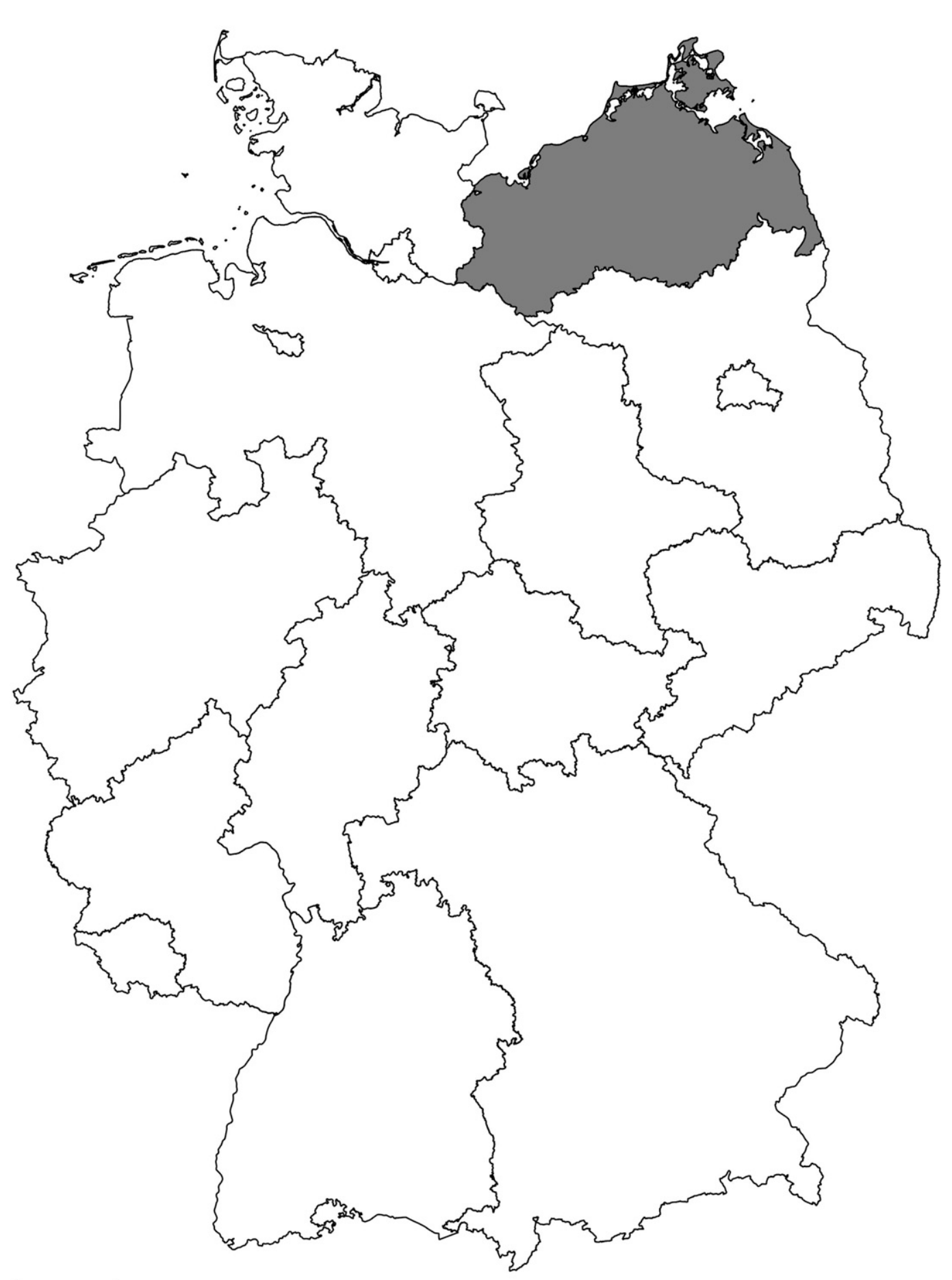

\section{Legend}

Mecklenburg-Vorpommern

Figure 1. Location of Mecklenburg-Western Pomerania in Germany (highlighted in gray). 


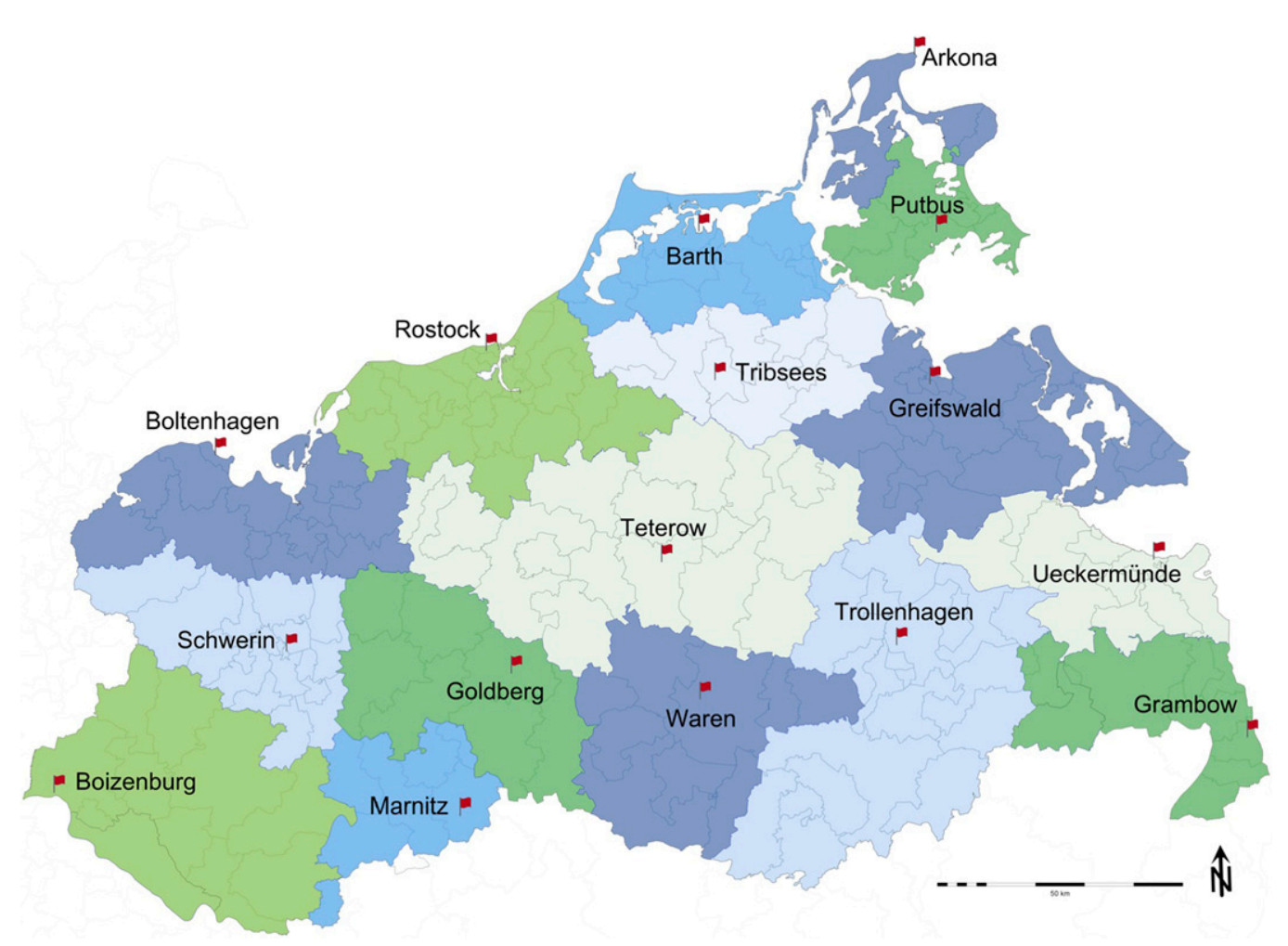

Figure 2. Location of the weather stations in Mecklenburg-Western Pomerania.

For example, Dixon et al. (1994) compare weather variables by developmental stage with variables by calendar month and find only minor deviations between the models with regard to forecasting quality. Gooding et al. (1997), Johansson and Svensson (1998), Dalla Marta et al. (2011), and Lee et al. (2013) also estimate their regressions by weather variables after calendar months.

For the harvest years 2004-15, ATR Landhandel GmbH and Co. KG provided the protein values of 148800 wheat deliveries from Mecklenburg-Western Pomerania. Each wheat delivery is sampled, and the protein content is analyzed during the collection phase in the warehouse of the agricultural trader to determine the quality. In addition to the protein content, the dataset at hand for each sample also documents the quantity of wheat delivered and the quality classification of the variety with regard to A or B wheat. "A wheat" requires a minimum protein content of $13.0 \%$ with regard to protein, and at least $12.0 \%$ protein is required for "B wheat." In addition, each sample is assigned to the postcode of the producing farm. This results in 78350 samples of A wheat, with a reference quantity of 1.88 million tons, and $70450 \mathrm{~B}$ wheat samples, with a total quantity of 1.85 million tons. This quality classification was integrated into the protein content prediction model as a dummy variable.

With the information mentioned above, the data were prepared as follows:

1) Based on the sampled quantity, weighted averages of the protein contents for each postcode district were initially calculated for the harvest years 
Earth Interactions • Volume 22 (2018) • Paper No. 19 • Page 9

Table 1. Descriptive statistics $(N=353)$.

\begin{tabular}{lrrrrrrrr}
\hline Parameter $^{\mathrm{a}}$ & Mean & Std dev & \multicolumn{1}{c}{ Min } & Max & Range & First quartile & Median & Third quartile \\
\hline Protein $(\%)$ & 12.94 & 0.66 & 10.97 & 14.68 & 3.71 & 12.43 & 12.98 & 13.41 \\
t4 $\left({ }^{\circ} \mathrm{C}\right)$ & 257.51 & 43.06 & 167.40 & 367.40 & 200.00 & 228.50 & 244.40 & 284.70 \\
t5 $\left({ }^{\circ} \mathrm{C}\right)$ & 382.01 & 36.89 & 265.90 & 458.50 & 192.60 & 362.50 & 386.80 & 407.60 \\
t6 $\left({ }^{\circ} \mathrm{C}\right)$ & 464.73 & 30.41 & 401.30 & 535.50 & 134.20 & 444.10 & 462.60 & 485.30 \\
t7 $\left({ }^{\circ} \mathrm{C}\right)$ & 573.53 & 52.03 & 481.50 & 713.20 & 231.70 & 535.90 & 562.10 & 604.40 \\
d4 $\left({ }^{\circ} \mathrm{C}\right)$ & 282.77 & 63.82 & 125.40 & 441.00 & 315.60 & 241.10 & 283.80 & 324.30 \\
d5 $\left({ }^{\circ} \mathrm{C}\right)$ & 304.50 & 68.01 & 141.50 & 500.90 & 359.40 & 255.30 & 310.40 & 348.40 \\
d6 $\left({ }^{\circ} \mathrm{C}\right)$ & 294.45 & 57.34 & 148.30 & 425.80 & 277.50 & 267.50 & 301.90 & 337.50 \\
d7 $\left({ }^{\circ} \mathrm{C}\right)$ & 304.73 & 66.56 & 137.80 & 479.60 & 341.80 & 263.30 & 303.40 & 350.60 \\
n4 $(\mathrm{mm})$ & 28.34 & 20.35 & 0.90 & 104.50 & 103.60 & 15.00 & 24.80 & 36.50 \\
n5 $(\mathrm{mm})$ & 56.38 & 28.79 & 5.80 & 131.70 & 125.90 & 37.20 & 51.40 & 75.00 \\
n6 $(\mathrm{mm})$ & 58.60 & 30.15 & 16.60 & 162.00 & 145.40 & 35.70 & 53.40 & 76.60 \\
n7 (mm) & 79.50 & 58.22 & 5.50 & 343.90 & 338.40 & 41.80 & 72.80 & 101.10 \\
s4 (h) & 213.27 & 54.42 & 89.30 & 342.40 & 253.10 & 176.50 & 213.15 & 252.00 \\
s5 (h) & 231.75 & 58.18 & 112.10 & 395.50 & 283.40 & 192.45 & 229.20 & 260.89 \\
s6 (h) & 237.90 & 44.12 & 142.02 & 318.60 & 176.58 & 202.80 & 245.13 & 271.30 \\
s7 (h) & 247.29 & 62.76 & 129.80 & 389.50 & 259.70 & 197.30 & 237.25 & 292.67 \\
\hline
\end{tabular}

${ }^{a}$ Parameter descriptions: $t$ is the temperature sum in a specific month, $d$ is the sum of daily temperature range in a specific month, $\mathrm{n}$ is the total precipitation in a specific month, and $\mathrm{s}$ is the sunshine hours in a specific month, and the numbers 4, 5, 6, and 7 correspond to the months of April, May, June, and July, respectively.

from 2004 to 2015. A distinction is made between the protein content of A and $\mathrm{B}$ wheat varieties.

2) Based on the procedure of Lee et al. (2013), the 150 postcode districts were grouped into 16 regions on the basis of their distance from the available weather stations. Only if there was more than one weather station per county were the postcode districts of this county divided according to their distance from the station.

3) In a final step, the protein contents of the postcode districts were aggregated into quantity-weighted averages based on the 16 weather station-defined regions. This results in a 353-observation dataset with protein content and weather data for 16 regions in the harvest years from 2004 to 2015.

A descriptive analysis of these data is presented in Table 1, with no distinction being made between A and B wheat. From the mean values of the weather parameters, it can be seen that the monthly aggregated totals from April to July increase for the mean temperature as well as for precipitation and sunshine hours during the spring.

\section{Results}

\subsection{Results of the deterministic part of the JP function}

Using the procedure described in section 2, a random intercept model for Equation (3) was estimated. The results for the fixed effects are shown in the appendix (Table A1). A marginal coefficient of determination $R^{2}$ of 0.7650 (i.e., the variance in the data), which can be explained solely by the fixed effects, is a convincing result, considering the exclusive use of weather data. This measure of 
Earth Interactions - Volume 22 (2018) • Paper No. 19 • Page 10

Table 2. Elasticities of the quadratic mean function.

\begin{tabular}{lrrrrrrrr}
\hline & & & & & & & \multicolumn{2}{c}{ Mann-Whitney } \\
Parameter & Mean & Std dev & Min & Max & First quartile & Median & Third quartile & U test $^{\text {b }}$ \\
\hline EL_t4 & -0.2617 & 0.3685 & -1.1444 & 0.8355 & -0.5023 & -0.2847 & -0.0147 & $p<0.001^{* * *}$ \\
EL_t5 & 0.4607 & 0.6779 & -1.2454 & 2.1053 & -0.0708 & 0.5596 & 0.9900 & $p<0.001^{* * *}$ \\
EL_t6 & -0.4427 & 1.0402 & -2.7506 & 2.4319 & -1.1696 & -0.5329 & 0.1975 & $p<0.001^{* * *}$ \\
EL_t7 & 0.3592 & 1.4061 & -2.8775 & 4.2675 & -0.6348 & 0.3971 & 1.1089 & $p<0.001^{* * *}$ \\
EL_d4 & -0.1127 & 0.2591 & -0.9255 & 0.4975 & -0.2889 & -0.1142 & 0.0714 & $p<0.001^{* * *}$ \\
EL_d5 & -0.0854 & 0.4878 & -1.9916 & 1.7559 & -0.3983 & -0.0755 & 0.1716 & $p<0.001^{* * *}$ \\
EL_d6 & 0.1229 & 0.3693 & -1.1622 & 0.9219 & -0.1459 & 0.1369 & 0.3913 & $p<0.001^{* * *}$ \\
EL_d7 & -0.0002 & 0.4168 & -1.4450 & 1.4389 & -0.2853 & -0.0034 & 0.2961 & $p=0.800$ \\
EL_n4 & 0.0158 & 0.0832 & -0.2433 & 0.2902 & -0.0199 & 0.0018 & 0.0557 & $p=0.005^{* *}$ \\
EL_n5 & 0.0094 & 0.1147 & -0.1586 & 0.5124 & -0.0686 & -0.0215 & 0.0577 & $p=0.200$ \\
EL_n6 & 0.1491 & 0.1670 & -0.2197 & 0.6807 & 0.0454 & 0.1189 & 0.2404 & $p<0.001^{* * *}$ \\
EL_n7 & -0.0105 & 0.0872 & -0.3311 & 0.2463 & -0.0601 & -0.0207 & 0.0356 & $p<0.001^{* * *}$ \\
EL_s4 & 0.1674 & 0.2085 & -0.2971 & 0.7531 & 0.0251 & 0.1657 & 0.3121 & $p<0.001^{* * *}$ \\
EL_s5 & -0.0562 & 0.3482 & -1.4668 & 0.6580 & -0.2299 & -0.0156 & 0.1451 & $p=0.090$ \\
EL_s6 & -0.0947 & 0.2194 & -0.7545 & 0.5234 & -0.2058 & -0.0808 & 0.0435 & $p<0.001^{* * *}$ \\
EL_s7 & -0.2460 & 0.4018 & -1.4789 & 0.7105 & -0.4824 & -0.2589 & 0.0086 & $p<0.001^{* * *}$ \\
\hline
\end{tabular}

${ }^{a}$ Parameter descriptions: $t$ is the temperature sum in a specific month, $d$ is the sum of daily temperature range in a specific month, $\mathrm{n}$ is the total precipitation in a specific month, and $\mathrm{s}$ is the sunshine hours in a specific month, and the numbers 4, 5, 6, and 7 correspond to the months of April, May, June, and July, respectively.

b Asterisks indicate the significance level: * is for $p<0.05$, ** is for $p<0.01$, and $* * *$ is for $p<0.001$.

determination without random effects reflects the variation in an area over several years and not between different regions. Comparable studies show similar meaningfulness in corresponding models (Smith and Gooding 1999; Pan et al. 2006; Jarvis et al. 2008). By adding the region-specific random intercept (not shown in Table A1), the explanatory power of the model can even be increased to a conditional $R^{2}$ of 0.8000 . However, the region-specific deviations from the common intercept do not differ significantly from zero $(p>0.1)$.

The only coefficient that can be directly interpreted from the estimation results (Table A1) is the dummy variable for wheat quality. Regardless of the weather, the protein content of A wheat varieties is, on average, $0.5217 \%$ higher than that of B wheat varieties. This was to be expected because A wheat varieties have a higher protein content than B wheat varieties for genetic reasons (Haumann et al. 2011).

Because of the quadratic functional form of the mean function, the results of the weather variables do not allow for a direct interpretation of the estimated coefficients. Therefore, elasticities were determined for all weather parameters shown in Table 2. For example, if the temperature sum increases by $1 \%$ in April, the protein content decreases by an average of $0.2617 \%$, holding all other variables constant. MannWhitney $U$ tests were used to test the null hypothesis that the elasticities are equal to zero. This null hypothesis can be rejected at any common significance level (except for precipitation in May) for the sum of daily temperature range in July and sunshine hours in May. When comparing the results of this study with literature, it should be noted that the allocation of developmental stages to corresponding months in different natural areas or countries can differ from one another and thus only indirectly draw conclusions (Dixon et al. 1994). 
Earth Interactions - Volume 22 (2018) • Paper No. 19 • Page 11

\subsubsection{Temperature sum}

The results in Table 2 show that temperature sum has a statistically significant influence on the protein content of wheat in the months of April-July. However, the influence does not have the same sign for all months. An increase in the temperature sum in April and June leads to a decrease in protein content, whereas a higher temperature sum in May and July leads to a higher protein level. It can be derived from the literature that a higher temperature has a positive influence on protein content explicitly in the grain-filling phase. In our research region, the grain-filling phase takes place around the middle/end of May. Some examples are the results of Rao et al. (1993), Johansson and Svensson (1998), Smith and Gooding (1999), Daniel and Triboi (2000), Pan et al. (2006), and Lee et al. (2013). Thus, for the filling phase, our results are in line with findings from the literature. An explanation for the positive elasticity in July may be related to the soluble starch synthase enzyme, which is extremely sensitive to high temperatures (Chinnusamy and Khanna-Chopra 2003). Thus, a higher temperature at this stage would reduce starch synthesis and increase the protein concentration in the grain.

The negative influence of the temperature in the growing month of April is not found in previous studies on the protein content of wheat. Only for triticale, Alaru et al. (2003) describe a negative effect of temperature after hibernation. Rharrabti et al. (2001) investigate the relationship between durum wheat yield and protein content and observe a strong negative correlation. Higher temperatures at the beginning of spring are likely to have a positive effect on yield and, due to the dilution effect of higher yields, a negative effect on protein content (Partridge and Shaykewich 1972; Campbell et al. 1981).

The changes in sign of the elasticities by month indicate the complexity of the wheat temperature response at different developmental stages. This could be partly an effect of the variations in developmental stage by month within the study area, as mentioned earlier.

Overall, it is observed that the elasticities for the monthly temperature are greater than the other weather parameters. The greater temperature influence compared to other weather parameters is consistent with previous studies (Campbell and Davidson 1979).

In the interpretation of our results, it should be considered that the standard deviation is comparatively high for the elasticity of temperature in June and July. This might influence the meaningfulness of the results.

\subsubsection{Sum of daily temperature range}

The descriptive data analysis of the weather parameters (Table 1) shows that the summed mean of the daily temperature range is relatively independent from the observation month. Nevertheless, an increase in the daily temperature range (i.e., major day-night variations in temperature) has different effects on the crude protein content of wheat during the analyzed months. The sum of the daily temperature ranges shows statistically significant negative elasticities in the months of April $(-0.1127)$ and May $(-0.0854)$, while in June there is a positive elasticity in the amount of 0.1229 . For all months, the size of the elasticities is smaller in comparison to the elasticities of the temperature sum. 
Earth Interactions - Volume 22 (2018) - Paper No. 19 • Page 12

The sign change of the elasticities in the individual months indicates that no simple physical explanation can be given for these effects. There are two situations that lead to a smaller daily temperature range. On the one hand, a reduced drop in nighttime temperature causes a smaller temperature range. On the other hand, a cooler daytime high has an equal effect. It can therefore be assumed that the temperature range has an influence on both daytime and nighttime physiological functions within a plant. Both during the day and after, the rate of mitochondrial respiration $R_{m}$ leading to biomass synthesis doubles, with an increase of $10^{\circ} \mathrm{C}$ (Sale 1974). Thus, a higher temperature at night would lead to a higher $R_{m}$, whereas a colder temperature during the day would have the opposite effect. Hay and Porter (2006) caution that respiration should not be considered in isolation when analyzing the effect of weather parameters on dry matter production, since factors such as the size and activity of the photosynthetic system and the receipt of solar radiation operate simultaneously.

To the best of our knowledge, only Pan et al. (2006) have used daily temperature ranges as explanatory variables for predicting the protein content until now. They found a significant positive influence of larger daily temperature ranges in Chinese high-protein wheat varieties with more than $15 \%$ crude protein content. However, their analysis focuses on a general influence of various weather parameters without separation into months.

\subsubsection{Precipitation}

Rainfall in April and June reveals a statistically significant positive elasticity of 0.0158 and 0.1491 , while a $1 \%$ precipitation increase in July leads to a decrease in protein content of 0.0105 . In May, the mean elasticity is positive; however, it is not significantly different from zero. Here, higher precipitation levels have a positive influence on protein formation, as they improve the uptake and conversion of nitrogen from the last fertilizer application (Gooding et al. 2003). Flagella et al. (2010) and Lee et al. (2013) measure and explain the higher protein content as a result of increased precipitation at the beginning of the grain-filling phase. In contrast, Johansson and Svensson (1998) find a negative correlation of protein content and rain in the grainfilling phase, and Lee et al. (2013) detect a negative relation between protein and precipitation for all investigated developmental stages of wheat. Our results only confirm this result for the month of July, when wheat ripening occurs. Yang and Zhang's (2006) results can explain this finding. They find that water stress during early grain development curtails the kernel sink potential by reducing the number of endosperm cells and amyloplasts formed. This leads to a reduction in grain weight, which would increase protein content.

However, it should be kept in mind that the absolute values of the elasticities are small in comparison to other weather parameters.

\subsubsection{Sunshine hours}

Our results reveal a significant positive effect of an increase in sunshine hours in April and the opposite effect for June and July. The positive elasticity during growth confirms the findings of Lee et al. (2013), while the negative elasticities in June and July are not in line with results from the literature. Neither Lee et al. (2013) nor Johansson and Svensson (1998) find a positive correlation of protein content and sunshine hours in spring and grain-filling phase. 
Earth Interactions - Volume 22 (2018) • Paper No. 19 • Page 13

There is an opposite elasticity of sunshine duration and temperature sum in July. Increasing protein contents with increasing temperature and decreasing levels due to higher radiation were detected by Benzian and Lane (1986), for example. The interaction between temperature and sunshine hours on protein content is complex and hard to explain. Radiation drives the gross photosynthesis process, which is mediated by the temperature during the day, while the respiration rate also responds to both day and night temperatures and with a different impact on crop growth at different stages during the growing season (Hay and Porter 2006).

\subsection{Results of the variance function}

The basic prerequisite for estimating the stochastic part of the production function is heteroscedasticity in the residuals of the function of the mean protein level. A suitable statistical test for this purpose is the Breusch-Pagan (BP) test. Since normally distributed errors of the considered regression are a prerequisite for the execution of the BP test, this assumption was statistically tested by means of a Kolmogorov-Smirnov test. This test indicates that the assumption of normal distribution of the error terms $u_{i t}$ from Equation (3) cannot be rejected $(p=0.700)$. The BP test shows that the null hypothesis of homoscedastic residuals can be rejected ( $p=0.008)$. Thus, heteroscedasticity is present in the residuals of the quadratic mean function, and the estimation of the variance function is justified. The results of the CD function are shown in Table 3.

In total, four coefficients are statistically significantly different from zero. A $1 \%$ increase in temperature sum in July leads ceteris paribus (c.p.) to an $8.6673 \%$ decrease in variance of protein content. Also, a $1 \%$ increase in the sum of the daily temperature range in July leads to a lower fluctuation in protein content by $4.1111 \%$. In contrast, a greater sum of the daily temperature range in June and an increasing sunshine duration in July leads to a higher variance in protein content. A $1 \%$ increase in the sum of daily temperature ranges in June leads c.p. to an increase in protein content's variance by $5.5768 \%$. The protein content's variance increases by $4.5445 \%$ when sunshine duration in July increases by $1 \%$, holding all other variables constant.

Finally, it has to be pointed out that only a small part of the protein content variance can be explained by the weather parameters included in the analysis. The conditional $R^{2}$ (i.e., the explanatory power of fixed and random effects) is 0.0794 . Excluding the random region-specific effects, the $R^{2}$ amounts to only 0.0676 (the random effects are not shown in the table). The meaningfulness of the variance function is correspondingly low. Since no prediction models for protein content of wheat have been estimated with JP models so far, it is difficult to make a direct comparison with other

studies. However, $R^{2}$ values for the risk functions of wheat yields in studies that also use JP functions are at a similar or only slightly higher level (Asche and Tveterås 1999; Carew et al. 2009; Cabas et al. 2010; Gardebroek et al. 2010).

\section{Conclusions}

The marketing of wheat requires consistent quality on one hand. On the other hand, knowledge of the expected wheat quality is necessary in order to make marketing decisions. The main quality characteristic for wheat, the protein content, is determined by weather parameters in addition to other factors. The exact influence of different weather parameters on the protein content of wheat and its variability has 
Earth Interactions • Volume 22 (2018) • Paper No. 19 • Page 14

Table 3. Results of the CD variance function. ${ }^{a}$ Marginal $R^{2}=0.0676$, and conditional $R^{2}=0.0794$. The random intercepts do not differ significantly from zero $(p>0.1)$.

\begin{tabular}{lrrrl}
\hline Parameter $^{\text {b }}$ & Estimate & Std error & $t$ value & $p$ value $^{\text {c }}$ \\
\hline Intercept & 32.9658 & 26.2910 & 1.2500 & 0.2114 \\
1_t4 & 0.7292 & 1.6507 & 0.4400 & 0.6591 \\
1_t5 & -2.4946 & 2.7768 & -0.9000 & 0.3698 \\
1_t6 & 3.0778 & 3.8475 & 0.8000 & 0.4244 \\
1_t7 & -8.6673 & 4.0096 & -2.1600 & $0.0314^{*}$ \\
1_d4 & 2.5423 & 1.7682 & 1.4400 & 0.1518 \\
1_d5 & -3.1311 & 1.8608 & -1.6800 & 0.0934 \\
1_d6 & 5.5768 & 2.4227 & 2.3000 & $0.0222^{*}$ \\
1_d7 & -4.1111 & 1.8688 & -2.2000 & $0.0285^{*}$ \\
1_n4 & -0.3002 & 0.2553 & -1.1800 & 0.2409 \\
1_n5 & -0.1034 & 0.3262 & -0.3200 & 0.7514 \\
1_n6 & -0.4626 & 0.3341 & -1.3800 & 0.1674 \\
1_n7 & 0.3844 & 0.3102 & 1.2400 & 0.2161 \\
1_s4 & -1.5354 & 1.4020 & -1.1000 & 0.2745 \\
1_s5 & -0.3023 & 1.2835 & -0.2400 & 0.8140 \\
1_s6 & -1.5648 & 1.4369 & -1.0900 & 0.2769 \\
1_s7 & 4.5445 & 1.6137 & 2.8200 & $0.0051^{*} *$ \\
Quality & -0.0937 & 0.2441 & -0.3800 & 0.7012 \\
\hline
\end{tabular}

${ }^{\text {a }}$ Sixteen regions/weather stations over 12 years with $n=353$ observations.

${ }^{b}$ Parameter descriptions: $t$ is the temperature sum in a specific month, $d$ is the sum of daily temperature range in a specific month, $\mathrm{n}$ is the total precipitation in a specific month, and $\mathrm{s}$ is the sunshine hours in a specific month, and the numbers 4, 5, 6, and 7 correspond to the months of April, May, June, and July, respectively. c Asterisks indicate the significance levels: * is for $p<0.05$, ** is for $p<0.01$, and $* * *$ is for $p<0.001$.

${ }^{\mathrm{d}}$ Dummy variable with $1=\mathrm{A}$ quality and $0=\mathrm{B}$ quality.

not yet been investigated for Germany. To close this research gap, a JP function has been estimated on the basis of these monthly weather parameters: temperature sum, daily temperature range, precipitation, and sunshine hours. The data were based on weather data from 16 weather stations in Mecklenburg-Western Pomerania and protein data from 148800 protein samples from 2004 to 2015. This data structure was taken into account by estimating a random intercept model.

Results for the mean and variance function for protein content show that a weather parameter can have different effects on the protein content depending on the month of observation. Higher temperatures lead to declining protein content in April and June, while in May and July, they have a positive effect on protein content. Furthermore, increasing daily temperature ranges decrease the protein content in April and May. The effect is opposite for the month of June. In addition, the results reveal that higher precipitation causes higher protein content in April and June and lower protein content in July. Moreover, it can be concluded that longer sunshine duration leads to an increase in April and a reduction of the predicted crude protein content in June and July. Independently from weather, the protein content of A wheat varieties is found to be $0.5217 \%$ higher than that of $\mathrm{B}$ varieties. This is a plausible result. For example, A wheat varieties are expected to have an average protein content of about $0.5 \%$ higher than $\mathrm{B}$ varieties. However, in addition to the higher protein content, other characteristics of the variety-in particular, yield expectations-must be taken into account when the farmer decides to cultivate it.

All in all, a marginal $R^{2}$ of 0.7650 reveals a high explanatory power for the estimation of mean protein content. From this, one can consider that the exclusive 
Earth Interactions - Volume 22 (2018) • Paper No. 19 • Page 15

use of the four weather parameters (temperature sum, precipitation, duration of sunshine, and daily temperature range) measured over a period of 4 months from April to July can explain more than $76.5 \%$ of the variance of the protein content. The parameters used are therefore a suitable basis for predicting the protein content to be expected in Mecklenburg-Western Pomerania. The model could provide valuable information with its current accuracy, especially at the initial recording of the harvest (e.g., by agricultural traders). In comparison to the farmer, for whom each individual delivery and thus also the variability of the protein content is important, the focus for agricultural traders is likely to be on significantly larger lots.

While the effects of the weather parameters on mean protein content might not be immediately apparent from a crop cultivation perspective, a mental link with the yield provides a clearer picture. It is known that there is a negative correlation between protein content and yield, so increasing yields are associated with decreasing protein content (Simmonds 1995). Declining yields and thus higher protein contents at rising temperatures or increasing yields and lower protein contents due to higher precipitation should suffice as examples. In this respect, the model should always be viewed in conjunction with the farmer's own yield expectations in order to further validate the forecast.

The results of the variance function are less meaningful compared to those of the mean protein-level function. While an increase in temperature and daily temperature ranges in July leads to more stable protein content, an increase in daily temperature ranges in June and more sunshine in July leads to higher fluctuation. However, due to the low explanatory power of the variance function, it must be stated that further research is still needed in order to determine the variability of the protein content.

For further research, the inclusion of nonweather parameters such as nitrogen fertilization could, for example, provide potential for improving the prediction of protein content and, in particular, its variability. In connection with nitrogen fertilization, interactions with weather parameters, especially precipitation, could provide interesting findings. In agricultural practice, it is generally known that late nitrogen fertilization combined with sufficient precipitation and soil moisture can increase the protein content of wheat (Haumann et al. 2011). Such an extended forecasting model would be useful for farmers, whereas there would be no further benefit for agricultural traders who do not have information on farm-specific wheat production technology. Another approach to improve the accuracy of the forecasting could be to adjust the observation periods to the actual growth stages of the wheat, rather than using a monthly approximation.

Acknowledgments. The authors would like to thank two anonymous referees and the editor for helpful comments and suggestions and also gratefully acknowledge financial support from German Research Foundation (DFG). Furthermore, the authors would like to thank Mrs. Katharine Michaelis and Mr. Wilken Hunze for their support in data preparation and the work on earlier drafts of this article.

\section{Appendix}

\section{Estimation Results and Additional Descriptive Statistics}

The appendix contains Tables A1-A4, which show, respectively, the results of the quadratic mean function and the mean, minimum, and maximum values of weather parameters by station and month. 
Earth Interactions • Volume 22 (2018) • Paper No. 19 • Page 16

Table A1. Results of the quadratic mean function. ${ }^{a}$ Marginal $R^{2}=0.7650$, and conditionall $R^{2}=0.8000$. The random intercepts do not differ significantly from zero $(p>0.1)$.

\begin{tabular}{|c|c|c|c|c|}
\hline Parameter $^{\mathrm{b}}$ & Estimate & Std error & $t$ value & $p$ value $^{\mathrm{c}}$ \\
\hline Intercept & -17.1002 & 33.1539 & -0.5200 & 0.6069 \\
\hline $\mathrm{t} 4$ & 0.2579 & 0.1176 & 2.1900 & $0.0317 *$ \\
\hline t5 & 0.0287 & 0.1276 & 0.2200 & 0.8225 \\
\hline t6 & 0.0235 & 0.1454 & 0.1600 & 0.8719 \\
\hline t7 & -0.1748 & 0.1326 & -1.3200 & 0.1909 \\
\hline $\mathrm{n} 4$ & 0.1734 & 0.2025 & 0.8600 & 0.3933 \\
\hline n5 & -0.0216 & 0.0871 & -0.2500 & 0.8044 \\
\hline n6 & -0.0939 & 0.0802 & -1.1700 & 0.2439 \\
\hline n7 & 0.1797 & 0.0758 & 2.3700 & $0.0189 *$ \\
\hline s4 & -0.0121 & 0.1366 & -0.0900 & 0.9297 \\
\hline s5 & 0.1061 & 0.1048 & 1.0100 & 0.3138 \\
\hline s6 & -0.0138 & 0.0891 & -0.1500 & 0.8771 \\
\hline s7 & 0.1471 & 0.0974 & 1.5100 & 0.1334 \\
\hline $\mathrm{d} 4$ & -0.0063 & 0.0763 & -0.0800 & 0.9341 \\
\hline $\mathrm{d} 5$ & -0.0713 & 0.0716 & -1.0000 & 0.3217 \\
\hline d6 & -0.0360 & 0.1122 & -0.3200 & 0.7490 \\
\hline $\mathrm{d} 7$ & 0.1316 & 0.0991 & 1.3300 & 0.1857 \\
\hline $\mathrm{I}\left(0.5 \times \mathrm{t} 4^{2}\right)$ & 0.0001 & 0.0003 & 0.2700 & 0.7845 \\
\hline $\mathrm{I}\left(0.5 \times \mathrm{t} 5^{2}\right)$ & 0.0000 & 0.0004 & -0.0700 & 0.9479 \\
\hline $\mathrm{I}\left(0.5 \times \mathrm{t} 6^{2}\right)$ & 0.0005 & 0.0006 & 0.9200 & 0.3603 \\
\hline $\mathrm{I}\left(0.5 \times \mathrm{t} 7^{2}\right)$ & 0.0009 & 0.0004 & 2.1700 & $0.0328 *$ \\
\hline $\mathrm{I}\left(0.5 \times \mathrm{n} 4^{2}\right)$ & 0.0003 & 0.0007 & 0.3500 & 0.7286 \\
\hline $\mathrm{I}\left(0.5 \times \mathrm{n} 5^{2}\right)$ & 0.0010 & 0.0003 & 3.4300 & $0.0009 * * *$ \\
\hline $\mathrm{I}\left(0.5 \times \mathrm{n} 6^{2}\right)$ & -0.0001 & 0.0003 & -0.4600 & 0.6457 \\
\hline $\mathrm{I}\left(0.5 \times \mathrm{n} 7^{2}\right)$ & 0.0000 & 0.0001 & -0.3400 & 0.7312 \\
\hline $\mathrm{I}\left(0.5 \times s 4^{2}\right)$ & -0.0001 & 0.0003 & -0.4100 & 0.6802 \\
\hline $\mathrm{I}\left(0.5 \times \mathrm{s} 5^{2}\right)$ & -0.0003 & 0.0002 & -1.7900 & 0.0784 \\
\hline $\mathrm{I}\left(0.5 \times \mathrm{s}^{2}\right)$ & 0.0001 & 0.0002 & 0.4500 & 0.6511 \\
\hline $\mathrm{I}\left(0.5 \times s 7^{2}\right)$ & 0.0003 & 0.0003 & 1.0700 & 0.2853 \\
\hline $\mathrm{I}\left(0.5 \times \mathrm{d} 4^{2}\right)$ & -0.0002 & 0.0002 & -1.1600 & 0.2497 \\
\hline $\mathrm{I}\left(0.5 \times \mathrm{d} 5^{2}\right)$ & -0.0001 & 0.0002 & -0.3800 & 0.7048 \\
\hline $\mathrm{I}\left(0.5 \times \mathrm{d} 6^{2}\right)$ & 0.0003 & 0.0003 & 0.9500 & 0.3451 \\
\hline $\mathrm{I}\left(0.5 \times \mathrm{d} 7^{2}\right)$ & -0.0004 & 0.0002 & -2.1500 & $0.0332 *$ \\
\hline $\mathrm{I}(\mathrm{t} 4 \times \mathrm{t} 5)$ & 0.0002 & 0.0002 & 0.8700 & 0.3859 \\
\hline $\mathrm{I}(\mathrm{t} 4 \times \mathrm{t} 6)$ & -0.0002 & 0.0003 & -0.7500 & 0.4586 \\
\hline $\mathrm{I}(\mathrm{t} 5 \times \mathrm{t} 6)$ & -0.0002 & 0.0004 & -0.4600 & 0.6488 \\
\hline $\mathrm{I}(\mathrm{t} 4 \times \mathrm{t} 7)$ & -0.0004 & 0.0002 & -1.8500 & 0.0659 \\
\hline $\mathrm{I}(\mathrm{t} 5 \times \mathrm{t} 7)$ & 0.0001 & 0.0003 & 0.4800 & 0.6298 \\
\hline $\mathrm{I}(\mathrm{t} 6 \times \mathrm{t} 7)$ & -0.0005 & 0.0004 & -1.1700 & 0.2458 \\
\hline $\mathrm{I}(\mathrm{t} 4 \times \mathrm{n} 4)$ & -0.0006 & 0.0003 & -1.8800 & 0.0641 \\
\hline $\mathrm{I}(\mathrm{t} 5 \times \mathrm{n} 4)$ & -0.0001 & 0.0004 & -0.3800 & 0.7047 \\
\hline $\mathrm{I}(\mathrm{t} 6 \times \mathrm{n} 4)$ & -0.0013 & 0.0006 & -2.2100 & $0.0338 *$ \\
\hline $\mathrm{I}(\mathrm{t} 7 \times \mathrm{n} 4)$ & 0.0014 & 0.0004 & 3.1800 & $0.0025 * *$ \\
\hline $\mathrm{I}(\mathrm{t} 4 \times \mathrm{n} 5)$ & 0.0000 & 0.0002 & -0.1700 & 0.8643 \\
\hline $\mathrm{I}(\mathrm{t} 5 \times \mathrm{n} 5)$ & 0.0000 & 0.0002 & -0.2200 & 0.8244 \\
\hline $\mathrm{I}(\mathrm{t} 6 \times \mathrm{n} 5)$ & -0.0006 & 0.0002 & -2.4200 & $0.0171 *$ \\
\hline $\mathrm{I}(\mathrm{t} 7 \times \mathrm{n} 5)$ & 0.0006 & 0.0002 & 2.5100 & $0.0129 *$ \\
\hline $\mathrm{I}(\mathrm{n} 4 \times \mathrm{n} 5)$ & 0.0002 & 0.0004 & 0.4500 & 0.6545 \\
\hline $\mathrm{I}(\mathrm{t} 4 \times \mathrm{n} 6)$ & 0.0000 & 0.0002 & 0.2500 & 0.8059 \\
\hline $\mathrm{I}(\mathrm{t} 5 \times \mathrm{n} 6)$ & 0.0003 & 0.0002 & 1.4700 & 0.1488 \\
\hline $\mathrm{I}(\mathrm{t} 6 \times \mathrm{n} 6)$ & -0.0001 & 0.0002 & -0.5300 & 0.6009 \\
\hline $\mathrm{I}(\mathrm{t} 7 \times \mathrm{n} 6)$ & 0.0002 & 0.0002 & 1.0000 & 0.3189 \\
\hline $\mathrm{I}(\mathrm{n} 4 \times \mathrm{n} 6)$ & 0.0004 & 0.0004 & 1.1700 & 0.2482 \\
\hline
\end{tabular}


Earth Interactions - Volume 22 (2018) • Paper No. 19 • Page 17

Table A 1. (Continued)

\begin{tabular}{|c|c|c|c|c|}
\hline Parameter $^{\mathrm{b}}$ & Estimate & Std error & $t$ value & $p$ value $^{\mathrm{c}}$ \\
\hline $\mathrm{I}(\mathrm{n} 5 \times \mathrm{n} 6)$ & 0.0000 & 0.0002 & -0.1200 & 0.9018 \\
\hline $\mathrm{I}(\mathrm{t} 4 \times \mathrm{n} 7)$ & 0.0002 & 0.0001 & 1.6900 & 0.0932 \\
\hline $\mathrm{I}(\mathrm{t} 5 \times \mathrm{n} 7)$ & -0.0002 & 0.0001 & -1.5000 & 0.1359 \\
\hline $\mathrm{I}(\mathrm{t} 6 \times \mathrm{n} 7)$ & 0.0002 & 0.0002 & 1.3500 & 0.1793 \\
\hline $\mathrm{I}(\mathrm{t} 7 \times \mathrm{n} 7)$ & -0.0003 & 0.0001 & -2.7900 & $0.0062 * *$ \\
\hline $\mathrm{I}(\mathrm{n} 4 \times \mathrm{n} 7)$ & -0.0001 & 0.0002 & -0.4800 & 0.6337 \\
\hline $\mathrm{I}(\mathrm{n} 5 \times \mathrm{n} 7)$ & 0.0000 & 0.0001 & 0.1200 & 0.9045 \\
\hline $\mathrm{I}(\mathrm{n} 6 \times \mathrm{n} 7)$ & -0.0002 & 0.0001 & -2.3400 & $0.0210 *$ \\
\hline $\mathrm{I}(\mathrm{t} 4 \times \mathrm{s} 4)$ & -0.0003 & 0.0002 & -1.4600 & 0.1458 \\
\hline $\mathrm{I}(\mathrm{t} 5 \times \mathrm{s} 4)$ & 0.0001 & 0.0002 & 0.3500 & 0.7252 \\
\hline $\mathrm{I}(\mathrm{t} 6 \times \mathrm{s} 4)$ & -0.0002 & 0.0002 & -1.0600 & 0.2904 \\
\hline $\mathrm{I}(\mathrm{t} 7 \times \mathrm{s} 4)$ & 0.0003 & 0.0002 & 1.3500 & 0.1786 \\
\hline $\mathrm{I}(\mathrm{n} 4 \times \mathrm{s} 4)$ & -0.0002 & 0.0004 & -0.5000 & 0.6219 \\
\hline $\mathrm{I}(\mathrm{n} 5 \times \mathrm{s} 4)$ & -0.0001 & 0.0002 & -0.3900 & 0.6996 \\
\hline $\mathrm{I}(\mathrm{n} 6 \times \mathrm{s} 4)$ & 0.0003 & 0.0002 & 1.8000 & 0.0747 \\
\hline $\mathrm{I}(\mathrm{n} 7 \times \mathrm{s} 4)$ & -0.0001 & 0.0001 & -0.6400 & 0.5260 \\
\hline $\mathrm{I}(\mathrm{t} 4 \times \mathrm{s} 5)$ & 0.0001 & 0.0001 & 0.5100 & 0.6086 \\
\hline $\mathrm{I}(\mathrm{t} 5 \times \mathrm{s} 5)$ & -0.0002 & 0.0002 & -1.4100 & 0.1604 \\
\hline $\mathrm{I}(\mathrm{t} 6 \times \mathrm{s} 5)$ & 0.0003 & 0.0002 & 1.2600 & 0.2127 \\
\hline $\mathrm{I}(\mathrm{t} 7 \times \mathrm{s} 5)$ & -0.0002 & 0.0002 & -0.9200 & 0.3571 \\
\hline $\mathrm{I}(\mathrm{n} 4 \times \mathrm{s} 5)$ & -0.0001 & 0.0002 & -0.5400 & 0.5911 \\
\hline $\mathrm{I}(\mathrm{n} 5 \times \mathrm{s} 5)$ & 0.0000 & 0.0002 & -0.2400 & 0.8139 \\
\hline $\mathrm{I}(\mathrm{n} 6 \times \mathrm{s} 5)$ & 0.0000 & 0.0001 & -0.1000 & 0.9176 \\
\hline $\mathrm{I}(\mathrm{n} 7 \times \mathrm{s} 5)$ & -0.0003 & 0.0001 & -3.0600 & $0.0027 * *$ \\
\hline $\mathrm{I}(\mathrm{s} 4 \times \mathrm{s} 5)$ & 0.0001 & 0.0002 & 0.6600 & 0.5112 \\
\hline $\mathrm{I}(\mathrm{t} 4 \times \mathrm{s} 6)$ & -0.0001 & 0.0001 & -0.9900 & 0.3270 \\
\hline $\mathrm{I}(\mathrm{t} 5 \times \mathrm{s} 6)$ & 0.0004 & 0.0003 & 1.3100 & 0.1932 \\
\hline $\mathrm{I}(\mathrm{t} 6 \times \mathrm{s} 6)$ & -0.0001 & 0.0003 & -0.4600 & 0.6455 \\
\hline $\mathrm{I}(\mathrm{t} 7 \times \mathrm{s} 6)$ & 0.0001 & 0.0002 & 0.7200 & 0.4723 \\
\hline $\mathrm{I}(\mathrm{n} 4 \times \mathrm{s} 6)$ & 0.0004 & 0.0003 & 1.2500 & 0.2143 \\
\hline $\mathrm{I}(\mathrm{n} 5 \times \mathrm{s} 6)$ & -0.0001 & 0.0002 & -0.6300 & 0.5277 \\
\hline $\mathrm{I}(\mathrm{n} 6 \times \mathrm{s} 6)$ & -0.0001 & 0.0002 & -0.4700 & 0.6356 \\
\hline $\mathrm{I}(\mathrm{n} 7 \times \mathrm{s} 6)$ & -0.0001 & 0.0001 & -0.4500 & 0.6523 \\
\hline $\mathrm{I}(\mathrm{s} 4 \times \mathrm{s} 6)$ & 0.0002 & 0.0002 & 0.9900 & 0.3250 \\
\hline $\mathrm{I}(\mathrm{s} 5 \times \mathrm{s} 6)$ & -0.0002 & 0.0002 & -0.8900 & 0.3727 \\
\hline $\mathrm{I}(\mathrm{t} 4 \times \mathrm{s} 7)$ & 0.0002 & 0.0002 & 1.0300 & 0.3035 \\
\hline $\mathrm{I}(\mathrm{t} 5 \times \mathrm{s} 7)$ & -0.0003 & 0.0002 & -1.2100 & 0.2283 \\
\hline $\mathrm{I}(\mathrm{t} 6 \times \mathrm{s} 7)$ & 0.0006 & 0.0003 & 2.0300 & $0.0448 *$ \\
\hline $\mathrm{I}(\mathrm{t} 7 \times \mathrm{s} 7)$ & -0.0007 & 0.0003 & -2.5000 & $0.0138 *$ \\
\hline $\mathrm{I}(\mathrm{n} 4 \times \mathrm{s} 7)$ & -0.0007 & 0.0005 & -1.5800 & 0.1184 \\
\hline $\mathrm{I}(\mathrm{n} 5 \times \mathrm{s} 7)$ & -0.0002 & 0.0002 & -0.8600 & 0.3923 \\
\hline $\mathrm{I}(\mathrm{n} 6 \times \mathrm{s} 7)$ & -0.0003 & 0.0001 & -2.0000 & $0.0475^{*}$ \\
\hline $\mathrm{I}(\mathrm{n} 7 \times \mathrm{s} 7)$ & 0.0002 & 0.0001 & 1.6700 & 0.0976 \\
\hline $\mathrm{I}(\mathrm{s} 4 \times \mathrm{s} 7)$ & -0.0002 & 0.0001 & -1.1200 & 0.2662 \\
\hline $\mathrm{I}(\mathrm{s} 5 \times \mathrm{s} 7)$ & 0.0002 & 0.0002 & 1.1900 & 0.2358 \\
\hline $\mathrm{I}(\mathrm{s} 6 \times \mathrm{s} 7)$ & -0.0003 & 0.0002 & -1.9000 & 0.0594 \\
\hline $\mathrm{I}(\mathrm{t} 4 \times \mathrm{d} 4)$ & 0.0001 & 0.0001 & 0.5600 & 0.5774 \\
\hline $\mathrm{I}(\mathrm{t} 5 \times \mathrm{d} 4)$ & 0.0000 & 0.0002 & -0.1400 & 0.8877 \\
\hline $\mathrm{I}(\mathrm{t} 6 \times \mathrm{d} 4)$ & 0.0001 & 0.0002 & 0.4900 & 0.6237 \\
\hline $\mathrm{I}(\mathrm{t} 7 \times \mathrm{d} 4)$ & 0.0000 & 0.0002 & 0.1900 & 0.8459 \\
\hline $\mathrm{I}(\mathrm{n} 4 \times \mathrm{d} 4)$ & -0.0002 & 0.0003 & -0.5600 & 0.5788 \\
\hline $\mathrm{I}(\mathrm{n} 5 \times \mathrm{d} 4)$ & -0.0002 & 0.0002 & -1.0300 & 0.3038 \\
\hline $\mathrm{I}(\mathrm{n} 6 \times \mathrm{d} 4)$ & -0.0003 & 0.0001 & -1.9400 & 0.0550 \\
\hline $\mathrm{I}(\mathrm{n} 7 \times \mathrm{d} 4)$ & 0.0000 & 0.0001 & -0.3400 & 0.7327 \\
\hline
\end{tabular}


Earth Interactions - Volume 22 (2018) • Paper No. 19 • Page 18

Table A 1. (Continued)

\begin{tabular}{|c|c|c|c|c|}
\hline Parameter $^{\mathrm{b}}$ & Estimate & Std error & $t$ value & $p$ value $^{\mathrm{c}}$ \\
\hline $\mathrm{I}(\mathrm{s} 4 \times \mathrm{d} 4)$ & 0.0002 & 0.0002 & 1.1900 & 0.2373 \\
\hline $\mathrm{I}(\mathrm{s} 5 \times \mathrm{d} 4)$ & -0.0001 & 0.0001 & -0.6500 & 0.5148 \\
\hline $\mathrm{I}(\mathrm{s} 6 \times \mathrm{d} 4)$ & -0.0001 & 0.0001 & -0.6200 & 0.5354 \\
\hline $\mathrm{I}(\mathrm{s} 7 \times \mathrm{d} 4)$ & 0.0000 & 0.0002 & 0.0900 & 0.9266 \\
\hline $\mathrm{I}(\mathrm{t} 4 \times \mathrm{d} 5)$ & -0.0003 & 0.0002 & -1.4600 & 0.1476 \\
\hline $\mathrm{I}(\mathrm{t} 5 \times \mathrm{d} 5)$ & 0.0000 & 0.0002 & 0.0900 & 0.9320 \\
\hline $\mathrm{I}(\mathrm{t} 6 \times \mathrm{d} 5)$ & 0.0000 & 0.0002 & 0.1700 & 0.8645 \\
\hline $\mathrm{I}(\mathrm{t} 7 \times \mathrm{d} 5)$ & 0.0002 & 0.0002 & 1.1600 & 0.2502 \\
\hline $\mathrm{I}(\mathrm{n} 4 \times \mathrm{d} 5)$ & 0.0006 & 0.0003 & 2.1800 & $0.0311 *$ \\
\hline $\mathrm{I}(\mathrm{n} 5 \times \mathrm{d} 5)$ & 0.0005 & 0.0002 & 2.1200 & $0.0379 *$ \\
\hline $\mathrm{I}(\mathrm{n} 6 \times \mathrm{d} 5)$ & 0.0000 & 0.0001 & -0.1100 & 0.9120 \\
\hline $\mathrm{I}(\mathrm{n} 7 \times \mathrm{d} 5)$ & 0.0003 & 0.0001 & 2.2300 & $0.0271 *$ \\
\hline $\mathrm{I}(\mathrm{s} 4 \times \mathrm{d} 5)$ & -0.0001 & 0.0001 & -0.8800 & 0.3791 \\
\hline $\mathrm{I}(\mathrm{s} 5 \times \mathrm{d} 5)$ & 0.0003 & 0.0001 & 2.3000 & $0.0237 *$ \\
\hline $\mathrm{I}(\mathrm{s} 6 \times \mathrm{d} 5)$ & 0.0000 & 0.0002 & -0.1500 & 0.8845 \\
\hline $\mathrm{I}(\mathrm{s} 7 \times \mathrm{d} 5)$ & -0.0004 & 0.0002 & -2.2100 & $0.0304 *$ \\
\hline $\mathrm{I}(\mathrm{d} 4 \times \mathrm{d} 5)$ & 0.0001 & 0.0002 & 0.4400 & 0.6640 \\
\hline $\mathrm{I}(\mathrm{t} 4 \times \mathrm{d} 6)$ & 0.0002 & 0.0002 & 0.8900 & 0.3736 \\
\hline $\mathrm{I}(\mathrm{t} 5 \times \mathrm{d} 6)$ & 0.0001 & 0.0003 & 0.3400 & 0.7356 \\
\hline $\mathrm{I}(\mathrm{t} 6 \times \mathrm{d} 6)$ & 0.0000 & 0.0003 & 0.0800 & 0.9345 \\
\hline $\mathrm{I}(\mathrm{t} 7 \times \mathrm{d} 6)$ & -0.0001 & 0.0002 & -0.6100 & 0.5458 \\
\hline $\mathrm{I}(\mathrm{n} 4 \times \mathrm{d} 6)$ & 0.0000 & 0.0004 & -0.0300 & 0.9793 \\
\hline $\mathrm{I}(\mathrm{n} 5 \times \mathrm{d} 6)$ & -0.0001 & 0.0003 & -0.2500 & 0.8061 \\
\hline $\mathrm{I}(\mathrm{n} 6 \times \mathrm{d} 6)$ & 0.0002 & 0.0002 & 0.9900 & 0.3246 \\
\hline $\mathrm{I}(\mathrm{n} 7 \times \mathrm{d} 6)$ & -0.0001 & 0.0001 & -0.6200 & 0.5363 \\
\hline $\mathrm{I}(\mathrm{s} 4 \times \mathrm{d} 6)$ & 0.0001 & 0.0002 & 0.5900 & 0.5569 \\
\hline $\mathrm{I}(\mathrm{s} 5 \times \mathrm{d} 6)$ & 0.0002 & 0.0002 & 0.9800 & 0.3328 \\
\hline $\mathrm{I}(\mathrm{s} 6 \times \mathrm{d} 6)$ & -0.0002 & 0.0002 & -1.1000 & 0.2737 \\
\hline $\mathrm{I}(\mathrm{s} 7 \times \mathrm{d} 6)$ & 0.0001 & 0.0002 & 0.2800 & 0.7805 \\
\hline $\mathrm{I}(\mathrm{d} 4 \times \mathrm{d} 6)$ & 0.0000 & 0.0002 & 0.1900 & 0.8477 \\
\hline $\mathrm{I}(\mathrm{d} 5 \times \mathrm{d} 6)$ & -0.0005 & 0.0002 & -2.0700 & $0.0416^{*}$ \\
\hline $\mathrm{I}(\mathrm{t} 4 \times \mathrm{d} 7)$ & 0.0001 & 0.0002 & 0.5200 & 0.6034 \\
\hline $\mathrm{I}(\mathrm{t} 5 \times \mathrm{d} 7)$ & -0.0001 & 0.0002 & -0.6800 & 0.4967 \\
\hline $\mathrm{I}(\mathrm{t} 6 \times \mathrm{d} 7)$ & 0.0000 & 0.0002 & 0.1700 & 0.8617 \\
\hline $\mathrm{I}(\mathrm{t} 7 \times \mathrm{d} 7)$ & -0.0002 & 0.0002 & -1.0300 & 0.3071 \\
\hline $\mathrm{I}(\mathrm{n} 4 \times \mathrm{d} 7)$ & -0.0006 & 0.0004 & -1.6200 & 0.1087 \\
\hline $\mathrm{I}(\mathrm{n} 5 \times \mathrm{d} 7)$ & -0.0003 & 0.0002 & -1.5900 & 0.1148 \\
\hline $\mathrm{I}(\mathrm{n} 6 \times \mathrm{d} 7)$ & 0.0000 & 0.0001 & -0.3100 & 0.7603 \\
\hline $\mathrm{I}(\mathrm{n} 7 \times \mathrm{d} 7)$ & -0.0002 & 0.0001 & -1.4900 & 0.1384 \\
\hline $\mathrm{I}(\mathrm{s} 4 \times \mathrm{d} 7)$ & -0.0001 & 0.0002 & -0.6300 & 0.5321 \\
\hline $\mathrm{I}(\mathrm{s} 5 \times \mathrm{d} 7)$ & -0.0004 & 0.0001 & -2.6300 & $0.0098 * *$ \\
\hline $\mathrm{I}(\mathrm{s} 6 \times \mathrm{d} 7)$ & 0.0002 & 0.0002 & 1.0000 & 0.3189 \\
\hline $\mathrm{I}(\mathrm{s} 7 \times \mathrm{d} 7)$ & 0.0003 & 0.0002 & 1.2600 & 0.2086 \\
\hline $\mathrm{I}(\mathrm{d} 4 \times \mathrm{d} 7)$ & -0.0001 & 0.0001 & -0.4600 & 0.6446 \\
\hline $\mathrm{I}(\mathrm{d} 5 \times \mathrm{d} 7)$ & 0.0004 & 0.0002 & 2.2800 & $0.0238 *$ \\
\hline $\mathrm{I}(\mathrm{d} 6 \times \mathrm{d} 7)$ & 0.0002 & 0.0002 & 1.0400 & 0.3029 \\
\hline Quality $^{\mathrm{d}}$ & 0.5217 & 0.0338 & 15.4300 & $<2 \times 10^{-16 * * *}$ \\
\hline
\end{tabular}

${ }^{\text {a }}$ Sixteen regions/weather stations over 12 years with $n=353$ observations.

b Parameter descriptions: $t$ is the temperature sum in a specific month, $d$ is the sum of daily temperature range in a specific month, $\mathrm{n}$ is the total precipitation in a specific month, and $\mathrm{s}$ is the sunshine hours in a specific month, and the numbers 4, 5, 6, and 7 correspond to the months of April, May, June, and July, respectively. c Asterisks indicate the significance levels: $*$ is for $p<0.05, * *$ is for $p<0.01$, and $* * *$ is for $p<0.001$.

${ }^{\mathrm{d}}$ Dummy variable with $1=$ A quality and $0=$ B quality. 
Earth Interactions V Volume 22 (2018) • Paper No. 19 • Page 19 
Earth Interactions - Volume 22 (2018) • Paper No. 19 • Page 20

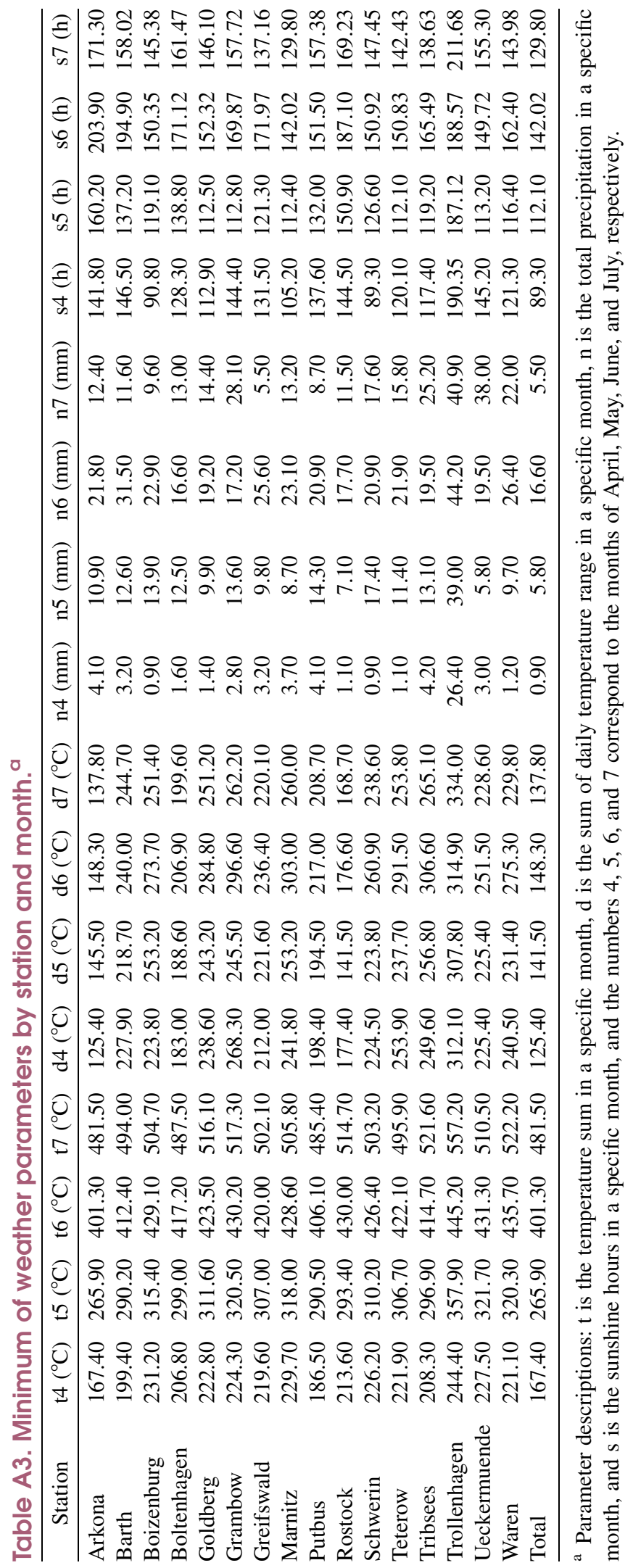


Earth Interactions V Volume 22 (2018) • Paper No. 19 • Page 21

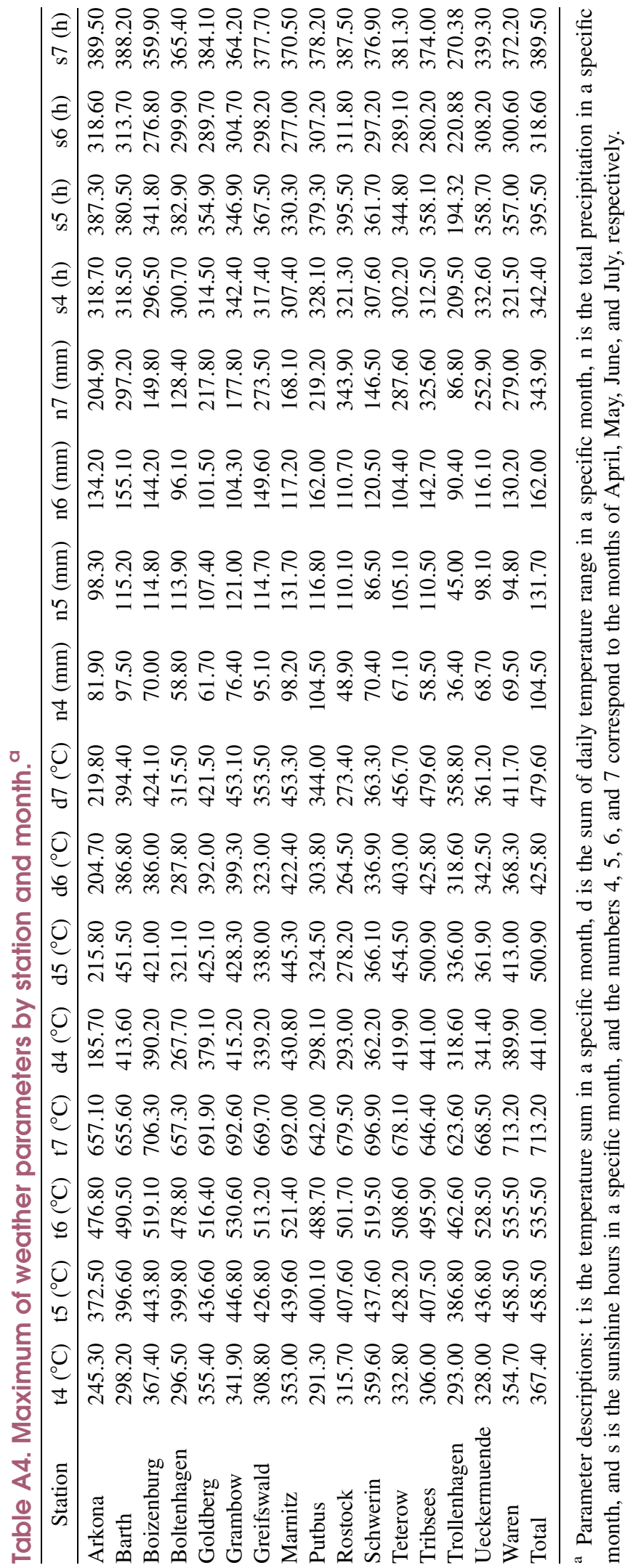


Earth Interactions - Volume 22 (2018) - Paper No. 19 • Page 22

\section{References}

Alaru, M., Ü. Laur, and E. Jaama, 2003: Influence of nitrogen and weather conditions on the grain quality of winter triticale. Agron. Res., 1, 3-10.

Asche, F., and R. Tveterås, 1999: Modeling production risk with a two-step procedure. J. Agric. Resour. Econ., 24, 424-439.

Bates, D., M. Mächler, B. Bolker, and S. Walker, 2015: Fitting linear mixed-effects models using lme4. J. Stat. Software, 67, 1-48, https://doi.org/10.18637/jss.v067.i01.

Benzian, B., and P. W. Lane, 1986: Protein concentration of grain in relation to some weather and soil factors during 17 years of English winter-wheat experiments. J. Sci. Food Agric., 37, 435-444, https://doi.org/10.1002/jsfa.2740370502.

Cabas, J., A. Weersink, and E. Olale, 2010: Crop yield response to economic, site and climatic variables. Climatic Change, 101, 599-616, https://doi.org/10.1007/s10584-009-9754-4.

Campbell, C. A., and H. R. Davidson, 1979: Effect of temperature, nitrogen fertilization and moisture stress on yield, yield components, protein content and moisture use efficiency of Manitou spring wheat. Can. J. Plant Sci., 59, 963-974, https://doi.org/10.4141/cjps79-153.

$\longrightarrow,-$, and G. E. Winkleman, 1981: Effect of nitrogen, temperature, growth stage and duration of moisture stress on yield components and protein content of Manitou spring wheat. Can. J. Plant Sci., 61, 549-563, https://doi.org/10.4141/cjps81-078.

Carew, R., E. G. Smith, and C. Grant, 2009: Factors influencing wheat yield and variability: Evidence from Manitoba, Canada. J. Agric. Appl. Econ., 41, 625-639, https://doi.org/ 10.1017/S1074070800003114.

Chen, C.-C., B. A. McCarl, and D. E. Schimmelpfennig, 2004: Yield variability as influenced by climate: A statistical investigation. Climatic Change, 66, 239-261, https://doi.org/10.1023/ B:CLIM.0000043159.33816.e5.

Chinnusamy, V., and R. Khanna-Chopra, 2003: Effect of heat stress on grain starch content in diploid, tetraploid and hexaploid wheat species. J. Agron. Crop Sci., 189, 242-249, https:// doi.org/10.1046/j.1439-037X.2003.00036.x.

Chmielewski, F.-M., and W. Köhn, 2000: Impact of weather on yield components of winter rye over 30 years. Agric. For. Meteor, 102, 253-261, https://doi.org/10.1016/S0168-1923(00)00125-8.

Climate Data, 2016: Klima: Mecklenburg-Vorpommern (Climate Mecklenburg-Western Pomerania). Climate-Data.org, accessed 15 October 2017, http://de.climate-data.org/region/423.

Dalla Marta, A., D. Grifoni, M. Mancini, G. Zipoli, and S. Orlandini, 2011: The influence of climate on durum wheat quality in Tuscany, Central Italy. Int. J. Biometeor, 55, 87-96, https://doi.org/ 10.1007/s00484-010-0310-8.

Daniel, C., and E. Triboi, 2000: Effects of temperature and nitrogen nutrition on the grain composition of winter wheat: Effects on gliadin content and composition. J. Cereal Sci., 32, 4556, https://doi.org/10.1006/jcrs.2000.0313.

Dixon, B. L., S. E. Hollinger, P. Garcia, and V. Tirupattur, 1994: Estimating corn yield response models to predict impact of climate change. J. Agric. Resour. Econ., 19, 58-68.

Eggert, H., and R. Tveterås, 2004: Stochastic production and heterogeneous risk preferences: Commercial fishers' gear choices. Amer. J. Agric. Econ., 86, 199-212, https://doi.org/ 10.1111/j.0092-5853.2004.00572.x.

Erekul, O., and W. Köhn, 2006: Effect of weather and soil conditions on yield components and bread-making quality of winter wheat (Triticum aestivum L.) and winter triticale (Triticosecale Wittm.) varieties in north-east Germany. J. Agron. Crop Sci., 192, 452-464, https:// doi.org/10.1111/j.1439-037X.2006.00234.x.

Fahrmeir, L., T. Kneib, S. Lang, and B. Marx, 2013: Regression: Models, Methods and Applications. Springer, $698 \mathrm{pp}$.

Flagella, Z., M. M. Giuliani, L. Giuzio, C. Volpi, and S. Masci, 2010: Influence of water deficit on durum wheat storage protein composition and technological quality. Eur. J. Agron., 33, 197207, https://doi.org/10.1016/j.eja.2010.05.006. 


\section{Earth Interactions - Volume 22 (2018) • Paper No. 19 • Page 23}

Gardebroek, C., M. D. Chavez, and A. O. Lansink, 2010: Analysing production technology and risk in organic and conventional Dutch arable farming using panel data. J. Agric. Econ., 61, 6075, https://doi.org/10.1111/j.1477-9552.2009.00222.x.

Gooding, M. J., G. Smith, W. P. Davies, and P. S. Kettlewell, 1997: The use of residual maximum likelihood to model grain quality characters of wheat with variety, climatic and nitrogen fertilizer effects. J. Agric. Sci., 128, 135-142, https://doi.org/10.1017/S0021859696004054.

— R. R. Ellis, P. R. Shewry, and J. D. Schofield, 2003: Effects of restricted water availability and increased temperature on the grain filling, drying and quality of winter wheat. J. Cereal Sci., 37, 295-309, https://doi.org/10.1006/jcrs.2002.0501.

Griffiths, W. E., and J. R. Anderson, 1982: Using time-series and cross-section data to estimate a production function with positive and negative marginal risks. J. Amer. Stat. Assoc., 77, 529536, https://doi.org/10.1080/01621459.1982.10477842.

Häner, L. L., and C. Brabant, 2016: Die Kunst, den Stickstoffdünger für einen optimalen Ertrag und Proteingehalt von Weizen aufzuteilen (The art of dividing the nitrogen fertilizer for an optimal yield and protein content of wheat). Agrarforsch. Schweiz, 7, 80-87, https://www.agrarforschungschweiz.ch/artikel/2016_02_2147.pdf.

Haumann, G., H. Dietzsch, and B. C. Schäfer, 2011: Halm- und Körnerfrüchte. Winter- und Sommerweizen (Triticum aestivum L.) (Crop and cereal fruits. Winter and summer wheat). Lehrbuch des Pflanzenbaues. Band 2: Kulturpflanzen (Plant Production Textbook: Volume 2: Cultivated Plants), N. Lütke Entrup and B. C. Schäfer, Eds., AgroConcept, 311416.

Hay, R. K. M., and J. R. Porter, 2006: The Physiology of Crop Yield. Wiley, 330 pp.

Jarvis, C. K., H. D. Sapirstein, P. R. Bullock, H. A. Naeem, S. V. Angadi, and A. Hussain, 2008: Models of growing season weather impacts on breadmaking quality of spring wheat from producer fields in western Canada. J. Sci. Food Agric., 88, 2357-2370, https://doi.org/ 10.1002/jsfa.3357.

Johansson, E., and G. Svensson, 1998: Variation in bread-making quality: Effects of weather parameters on protein concentration and quality in some Swedish wheat cultivars grown during the period 1975-1996. J. Sci. Food Agric., 78, 109-118, https://doi.org/10.1002/(SICI)10970010(199809)78:1<109::AID-JSFA92>3.0.CO;2-0.

Just, R. E., and R. D. Pope, 1978: Stochastic specification of production functions and economic implications. J. Econom., 7, 67-86, https://doi.org/10.1016/0304-4076(78)90006-4.

- , and -1979 : Production function estimation and related risk considerations. Amer. J. Agric. Econ., 61, 276-284, https://doi.org/10.2307/1239732.

Koch, M., 2011: Sortenspezifische Unterschiede beim Proteingehalt (Variety-specific differences in protein content). Innovation, 3/2011, 12-13, https://www.magazin-innovation.de/ export/sites/magazin-innovation.de/extras/dokumente/innovation-ab-3-2010/proteingehalt-3-11.pdf.

Koundouri, P., and C. Nauges, 2005: On production function estimation with selectivity and risk considerations. J. Agric. Resour. Econ., 30, 597-608.

Lee, B.-H., P. Kenkel, and B. W. Brorsen, 2013: Pre-harvest forecasting of county wheat yield and wheat quality using weather information. Agric. For. Meteor., 168, 26-35, https://doi.org/ 10.1016/j.agrformet.2012.08.010.

Moschini, G., and D. A. Hennessy, 2001: Uncertainty, risk aversion, and risk management for agricultural producers. Agricultural Production, B. L. Gardner and G. C. Rausser, Eds., Elsevier, 87-153, https://doi.org/10.1016/S1574-0072(01)10005-8.

Pan, J., Y. Zhu, W. Cao, T. Dai, and D. Jiang, 2006: Predicting the protein content of grain in winter wheat with meteorological and genotypic factors. Plant Prod. Sci., 9, 323-333, https://doi. org/10.1626/pps.9.323.

Partridge, J. R. D., and C. F. Shaykewich, 1972: Effects of nitrogen, temperature, and moisture regime on the yield and protein content of Neepawa wheat. Can. J. Soil Sci., 52, 179-185, https://doi.org/10.4141/cjss72-022. 
Earth Interactions - Volume 22 (2018) • Paper No. 19 • Page 24

Peterson, C. J., R. A. Graybosch, D. R. Shelton, and P. S. Baenziger, 1998: Baking quality of hard winter wheat: Response of cultivars to environment in the Great Plains. Euphytica, 100, 157162, https://doi.org/10.1023/A:1018361502435.

Porter, J. R., and M. A. Semenov, 2005: Crop responses to climatic variation. Philos. Trans. Roy. Soc. London, 360B, 2021-2035, https://doi.org/10.1098/rstb.2005.1752.

Qian, B., R. de Jong, R. Warren, A. Chipanshi, and H. Hill, 2009: Statistical spring wheat yield forecasting for the Canadian prairie provinces. Agric. For. Meteor., 149, 1022-1031, https:// doi.org/10.1016/j.agrformet.2008.12.006.

Rao, A. C. S., J. L. Smith, V. K. Jandhyala, R. I. Papendick, and J. F. Parr, 1993: Cultivar and climatic effects on the protein content of soft white winter wheat. Agron. J., 85, 1023-1028, https://doi.org/10.2134/agronj1993.00021962008500050013x.

Rharrabti, Y., D. Villegas, L. F. G. del Moral, N. Aparicio, S. Elhani, and C. Royo, 2001: Environmental and genetic determination of protein content and grain yield in durum wheat under Mediterranean conditions. Plant Breed., 120, 381-388, https://doi.org/10.1046/ j.1439-0523.2001.00628.x.

Sale, P. J. M., 1974: Productivity of vegetable crops in a region of high solar input. III. Carbon balance of potato crops. Aust. J. Plant Physiol., 1, 283-296, https://doi.org/10.1071/ PP9740283.

Semenov, M. A., 2009: Impacts of climate change on wheat in England and Wales. J. Roy. Soc. Interface, 6, 343-350, https://doi.org/10.1098/rsif.2008.0285.

Simmonds, N. W., 1995: The relation between yield and protein in cereal grain. J. Sci. Food Agric., 67, 309-315, https://doi.org/10.1002/jsfa.2740670306.

Smith, G. P., and M. J. Gooding, 1999: Models of wheat grain quality considering climate, cultivar and nitrogen effects. Agric. For. Meteor, 94, 159-170, https://doi.org/10.1016/S0168-1923(99)00020-9.

Statistisches Bundesamt, 2017: Land- und Forstwirtschaft, Fischerei. Bodennutzung der Betriebe (Landwirtschaftlich genutzte Flächen) 2016 [Agriculture and forestry, fisheries: Land use on farms (agricultural land) 2016]. Destatis Rep., 61 pp., https:/www.destatis.de/DE/Publikationen/ Thematisch/LandForstwirtschaft/Bodennutzung/LandwirtschaftlicheNutzflaeche2030312177004. pdf?_blob=publicationFile.

Stone, P. J., and R. Savin, 1999: Grain quality and its physiological determinants. Wheat: Ecology and Physiology of Yield Determination, E. H. Satorre and G. A. Slafer, Eds., Food Products Press, 114-122.

Tveterås, R., and G. H. Wan, 2000: Flexible panel data models for risky production technologies with an application to salmon aquaculture. Econom. Rev., 19, 367-389, https://doi.org/ 10.1080/07474930008800477.

Yang, J., and J. Zhang, 2006: Grain filling of cereals under soil drying. New Phytol., 169, 223-236, https://doi.org/10.1111/j.1469-8137.2005.01597.x.

Earth Interactions is published jointly by the American Meteorological Society, the American Geophysical Union, and the Association of American Geographers. For information regarding reuse of this content and general copyright information, consult the AMS Copyright Policy (www.ametsoc.org/PUBSReuseLicenses). 